九州大学学術情報リポジトリ

Kyushu University Institutional Repository

\title{
Reversible or Irreversible Change of Molecular Dynamics of Water in Pea Seedlings Exposed to Heaat Stress
}

Inoue, Mar i

Laboratory of Crop Science, Division of Agricultural Botany, Department of Plant Resoruces, Faculty of Agriculture, Kyushu University

Motooka, Kei

Laboratory of Horticultural Science, Department of Agronomy, Graduate School of Agriculture, Kyushu University

Nakamoto, Hiroaki

Fukuyama, Masataka

Laboratory of Crop Science, Division of Agricultural Botany, Department of Plant

Resoruces, Faculty of Agriculture, Kyushu University

https://doi.org/10.5109/4563

出版情報 : 九州大学大学院農学研究院紀要. 49 (1)，pp.39-47，2004-02-01. Faculty of Agriculture， Kyushu University

バージョン :

権利関係 : 


\title{
Reversible or Irreversible Change of Molecular Dynamics of Water in Pea Seedlings Exposed to Heat Stress
}

\author{
Mari IWAYA-INOUE*, Kei MOTOOKA ${ }^{1}$, Hiroaki NAKAMOTO ${ }^{2}$ \\ and Masataka FUKUYAMA
}

\author{
Laboratory of Crop Science, Division of Agricultural Botany, Department of Plant Resources, \\ Faculty of Agriculture, Kyushu University, Fukuoka 812-8581, Japan \\ (Received October 31, 2003 and accepted November 14, 2003)
}

\begin{abstract}
Influences of heat stress on epicotyls of pea (Pisum sativum L.) plants were investigated by using non-destructive method. NMR spin-lattice relaxation time $\left(T_{1}\right)$, indicating molecular dynamics of water, was determined in tall type, cv. Alaska and dwarf type, cv. Progress No. 9 seedlings grown under light condition. In no-elongation zone for both fresh cultivars a rapid decrease in $T_{1}$ occurred in the tissues exposed to $20-30^{\circ} \mathrm{C}$ while rapid increase followed by gradual decrease occurred in $T_{1}$ for the tissues exposed to $20-40^{\circ} \mathrm{C}$ during a heat-cool cycle. On the other hand, in heat-denatured dead tissues, $T_{1}$ linearly corresponded. Further, when pea plants were heated for $5 \mathrm{~h}$ at $20-30^{\circ} \mathrm{C}$ or $20-40^{\circ} \mathrm{C}$ thermal hysteresis changes in $T_{1}$ corresponding temperature in the subsequent heat-cool cycles was notably different. Epicotyls exposed to $30^{\circ} \mathrm{C}$ treatments did not show temperature dependency while those of the tissues exposed to $40^{\circ} \mathrm{C}$ indicated temperature dependency. After the subsequent heat-cool cycles, the former was alive, the latter indicated tissue necrosis. Therefore, the change in $T_{1}$ of epicotyls observed within $1 \mathrm{~h}$ was considered a fast adaptation or mortality in cells to heat stress, and a temperature dependency of $T_{1}$ in the subsequent heat-cool cycles clearly reflected tissue viability in pea epicotyls. In conclusion, $T_{1}$ on thermal response can be used as an indicator of reversible or irreversible injury in an intact plant.
\end{abstract}

\section{INTRODUCTION}

Heat stress induces various physiological changes in organelles of pea (Pisum sativum L.) plants (Galvis et al., 2001; Salvucci et.al., 2001, references therein). A $3 \mathrm{~h}$ treatment at $40^{\circ} \mathrm{C}$ of pea (var. Douce Provence) plants induces production and accumulation of a small heat-shock protein, HSP22, in the matrix compartment of mitochondria (Lenne and Douce, 1994). Furthermore, a partial HSP21 complex purified from heat-stressed pea leaves contained no proteins other than HSP21 (Suzuki et al., 1998). On the contrary, treatment at $40^{\circ} \mathrm{C}$ to pea plants led to a serious injury of the photosynthetic apparatus as seen in a sharp increase of the ground Chl fluorescence Fo and a decrease of the variable Chl fluorescence $\mathrm{Fv}$ and the ratios $\mathrm{Fv} / \mathrm{Fm}$ while the changes in $\mathrm{Chl}$ fluorescence parameters at $35^{\circ} \mathrm{C}$ were reversible (Georgieva and Lichtenthaler, 1999). Further, $38^{\circ} \mathrm{C}$ treatment caused an immediate decline of net D1 synthesis in pea plants (Franco et al., 1999). Therefore, temperatures around $40^{\circ} \mathrm{C}$ seem to set the tem-

\footnotetext{
1 Laboratory of Horticultural Science, Department of Agronomy, Graduate School of Agriculture, Kyushu University; present address, Kumamoto prefecture government, Hitoyoshi City.

Laboratory of Crop Science, Division of Agricultural Botany, Department of Plant Resources, Graduate School of Bioresource and Bioenvironmental Sciences, Kyushu University

* Corresponding author (E-mail: mariino@agr.kyushu-u.ac.jp)
} 
perature limits for studies on the heat acclimation or heat injury mechanisms of pea plants.

Besides, temperature response in pea seedlings was determined by using a diagnostic tool for monitoring the primary response of cells (Kaku and Iwaya-Inoue, 1988). A thermal hysteresis for nuclear magnetic resonance (NMR) spin-lattice relaxation time $\left(T_{1}\right)$ in pea seedlings following a slow cool-warm cycle, between 20 to $0^{\circ} \mathrm{C}$, indicated that pea plants were chilling resistant. Additionally, there was no phase change in $T_{1}$ of epicotyls for pea plants while a phase transition was observed in chilling sensitive plants such as Vigna radiata and $V$. mungo seedlings (Iwaya-Inoue et al., 1989). NMR allows nondestructive determination of each unique type of an NMR-active atom present in a molecule, how many of those atoms are present in the molecule. And thus both $T_{1}$ and spin-spin relaxation time $\left(T_{2}\right)$ were used as indicators of molecular dynamics of water in tissues (Ishida et al., 2000; Iwaya-Inoue and Nonami, 2003a, references therein). By using the parameter, sensitivity to various stresses of each species appears to be related to the severity of conditions in its natural habitats; leaves of azalea species with higher sensitivity to an environmental stress also exhibit higher sensitivity to other stresses and vice versa (Kaku, 1993). We have reported that dwarf type of pea was more drought resistant compared to the tall type (Iwaya-Inoue et al., 2003b).

Otherwise, when pea plants were heated for $10-60 \mathrm{~min}$ at $42^{\circ} \mathrm{C}$, a reversible shift of the prooxidant-antioxidant equilibrium towards stimulation of lipid peroxidation, observed in chloroplasts after around 15-min heat treatment, is considered a fast adaptive response of cells to hyperthermia (Kurganova et al., 1999). In addition, pea (cv. Feltham First) exposed to a heat stress of $37^{\circ} \mathrm{C}$ for $6 \mathrm{~h}$ accumulated $22 \mathrm{kDa}-\mathrm{HSPs}$ and the response to heat shock was rapid with protein expression detected within $45 \mathrm{~min}$ (Wood et al., 1998). Although mechanism of thermo-tolerance in pea plants has been extensively studied, little is known about time dependent changes in intact pea plants. Therefore, it is important to study dynamic states of water which affect cellular metabolism and to address the possibility of the primary response in the epicotyl tissues subjected to heat stress with non-destructive method. This study has two objectives: first, to determine characteristics of $T_{1}$ in intact fresh tissues of pea exposed to heat stress; and, second, to determine characteristics of $T_{1}$ in relation to dwarfism during subsequent heat-cool thermal hysteresis.

\section{MATERIALS AND METHODS}

\section{Plant materials}

Tall type of pea (Pisum sativum L.) cv. Alaska obtaining from commercial sources was used. Furthermore, seeds of dwarf genotype, cv. Progress No. 9, were provided by Dr. M. Katsumi. Two cultivars of pea were cultivated in a growth cabinet (Koitotron HNB-10A) at about $22^{\circ} \mathrm{C}$ with a photoperiod of $14 \mathrm{~h}$ light/10 h dark. Fluorescent lamps (FLR20S W/M 20W $\times 4$ ) were used as a luminous source. 10 to 12 day-old seedlings were used as materials. $100 \mu \mathrm{M} \mathrm{GA}_{1}$ was sprayed on an apex of 5 day-old seedlings of $\mathrm{cv}$. Progress No. 9 grown under light condition. Epicotyls of the second node from the apex part as elongation zone or basal part as no-elongation zone were cut from the intact pea seedlings and they were used following experiments. 


\section{Measurements of proton $T_{1}$ relaxation times}

Epicotyl tissues (each about $20 \mathrm{~mm}$ in length) were packed into a $7.5 \mathrm{~mm}$ diameter NMR tube. NMR measurements were made at $20 \mathrm{MHz}$ on a Bruker Minispec PC20 pulsed NMR spectrometer as described previously (Iwaya-Inoue et al., 1993). The $T_{1}$ values of epicotyls were measured by inversion recovery method using a $180^{\circ}-\tau-90^{\circ}$ pulse sequence (Farrar and Becker, 1971). The probe temperature was controlled by a thermostat (Lauda Kryo-SK65) connected to the sample chamber of the spectrometer, and NMR tubes without caps to allow air ventilation were used. Thus both measurements of $T_{1}$ and temperature treatments were carried out under aerobic conditions.

\section{Heating and cooling treatment}

For the slow heat-cool cycle, the temperature of the epicotyls was elevated gradually from 20 to $40^{\circ} \mathrm{C}$ and vice versa. Control experiment was carried out in the temperature range from 20 to $30^{\circ} \mathrm{C}$ and vice versa. Temperature was increased from 20 to $40^{\circ} \mathrm{C}$ or 20 to $30^{\circ} \mathrm{C}$ in $30 \mathrm{~min}$, subsequently samples were allowed to equilibrate for $60 \mathrm{~min}$ at 40 or $30^{\circ} \mathrm{C}$, respectively (Figs. 1 and 2). They were kept at these equilibrated temperatures for $30 \mathrm{~min}$ and then they were treated to the second and third subsequent heat-cool cycles, and the thermal hysteresis lasted about $5 \mathrm{~h}$ (Fig. 3). The probe temperature and heating-cooling rate were obtained by a programmatic thermal regulator (Chino JP series) and thyristor regulator (Chino SF-V 22) attached to the refrigerated thermostat described above. It was done four replications for each cultivar and Figures indicate typical profiles in individual experimental series.

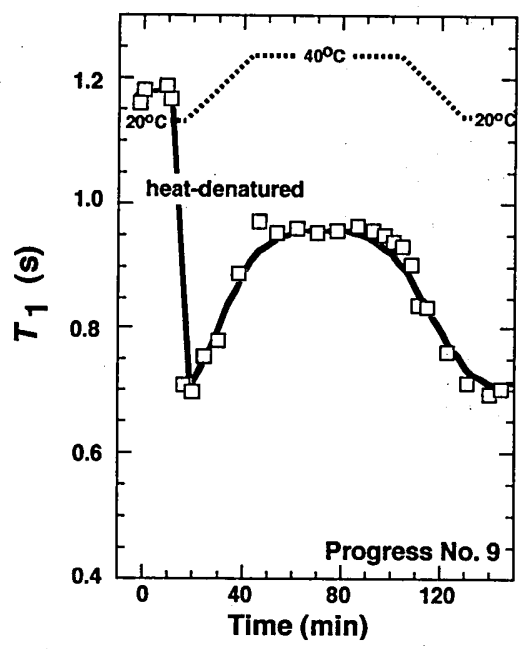

Fig. 1. Typical profile of thermal hysteresis of $T_{1}$ during a slow heat-cool cycle for pea (Pisum sativum L.) cv. Progress No. 9 epicotyls. Broken lines indicate temperature cycle for treatment as follows: before treatment $\left(20^{\circ} \mathrm{C}\right)$ followed by heat treatment $\left(40^{\circ} \mathrm{C}\right)$ and cool treatment $\left(20^{\circ} \mathrm{C}\right)$. 

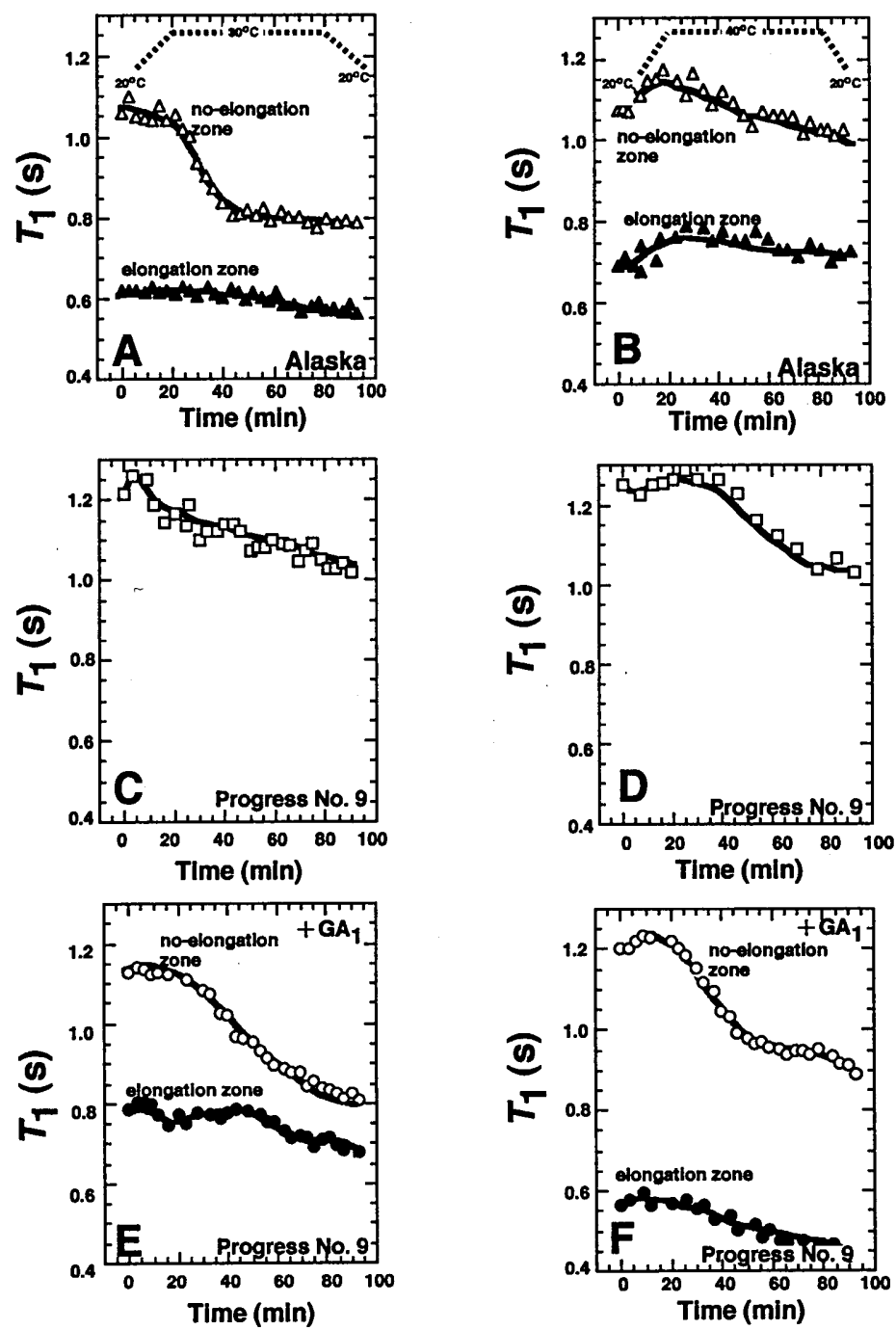

Fig. 2. Typical profiles of thermal hysteresis of $T_{1}$ during a slow heat-cool cycle for pea plant cultivars. (A) $T_{1}$ of cv. Alaska during $20-30^{\circ} \mathrm{C}$ cycle. (B) $T_{1}$ of cv. Alaska during $20-40^{\circ} \mathrm{C}$ cycle. (C) $T_{1}$ of cv. Progress No. 9 during $20-30^{\circ} \mathrm{C}$ cycle. (D) $T_{1}$ of cv. Progress No. 9 during $20-40^{\circ} \mathrm{C}$ cycle. (E) $T_{1}$ in $\mathrm{GA}_{1}$-dosed cv. Progress No. 9 during 20-30 ${ }^{\circ} \mathrm{C}$ cycle. (E) $T_{1}$ in $\mathrm{GA}_{1}$-dosed cv. Progress No. 9 during $20-40^{\circ} \mathrm{C}$ cycle. Open symbols indicate no-elongation zone and closed symbols indicate elongation zone in each cultivar. Triangles indicate $T_{1} \mathrm{~S}$ of Alaska, squires indicate those of Progress No. 9 and circles indicate those of $\mathrm{GA}_{1}$ treated Progress No. 9. Broken lines in (A) indicate temperature cycle for treatment as follows: before treatment $\left(20^{\circ} \mathrm{C}\right)$ followed by heat treatment $\left(30^{\circ} \mathrm{C}\right)$ and cool treatment $\left(20^{\circ} \mathrm{C}\right)$, and the same treatment is not shown in both $\mathrm{C}$ and $\mathrm{E}$. Broken lines in (B) indicate temperature cycle for treatment as follows: before treatment $\left(20^{\circ} \mathrm{C}\right)$ followed by heat treatment $\left(40^{\circ} \mathrm{C}\right)$ and cool treatment $\left(20^{\circ} \mathrm{C}\right)$, and the same treatment is not shown in both $\mathrm{D}$ and $\mathrm{F}$. 

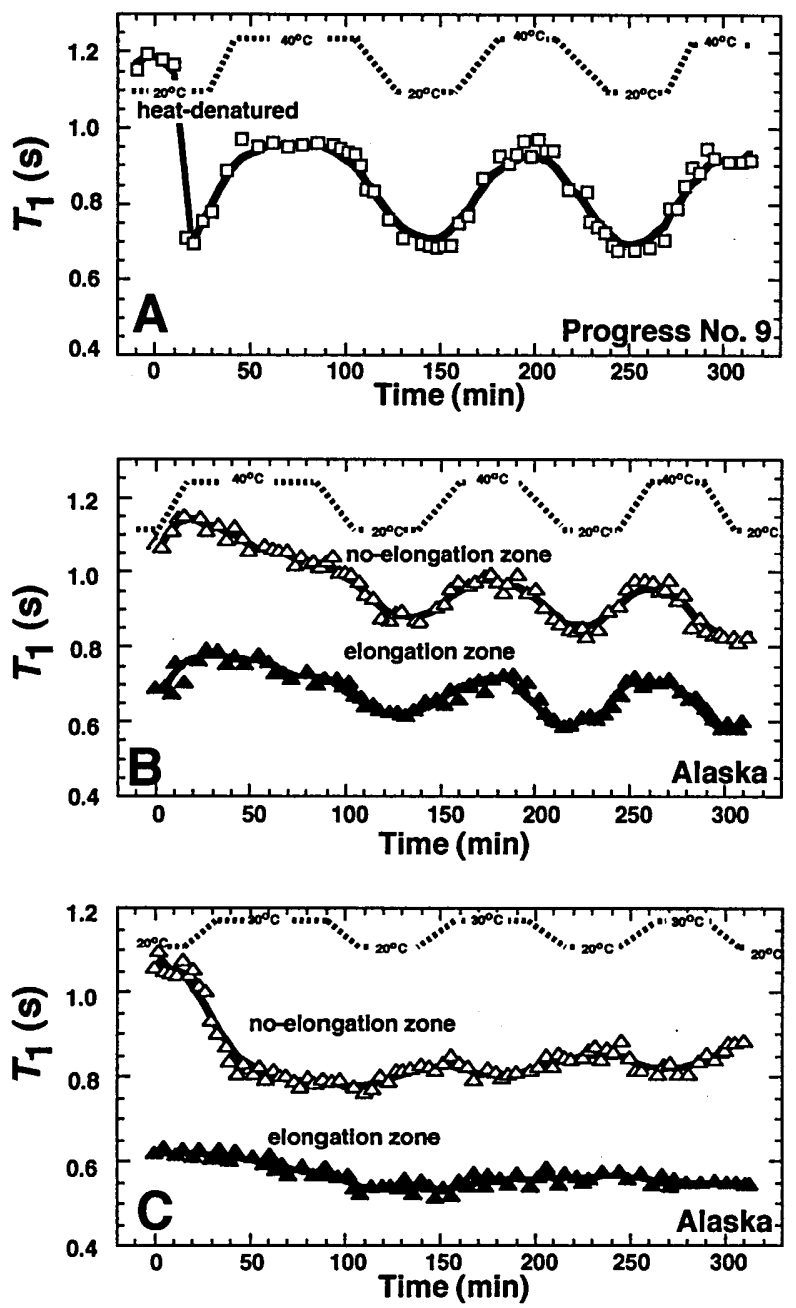

Fig. 3. Typical profiles of thermal hysteresis of $T_{1}$ during subsequent slow heat-cool cycles for pea epicotyls. (A) $T_{1}$ of cv. Progress No. 9 in $20-40{ }^{\circ} \mathrm{C}$ cycles. (B) $T_{1}$ of cv. Alaska in $20-40^{\circ} \mathrm{C}$ cycles. (C) $T_{1}$ of $\mathrm{cv}$. Alaska in $20-30^{\circ} \mathrm{C}$ cycles. Broken lines in (A and B) indicate temperature cycles for treatment as follows: before treatment $\left(20^{\circ} \mathrm{C}\right)$ followed by heat treatment $\left(40^{\circ} \mathrm{C}\right)$ and cool treatment $\left(20^{\circ} \mathrm{C}\right)$. Broken lines in $(\mathrm{C})$ indicate temperature cycles for treatment as follows: before treatment $\left(20^{\circ} \mathrm{C}\right)$ followed by heat treatment $\left(30^{\circ} \mathrm{C}\right)$ and cool treatment $\left(20^{\circ} \mathrm{C}\right)$. 


\section{RESULTS AND DISCUSSION}

\section{Thermal hysteresis of $T_{1}$ in heat-denatured pea seedlings}

NMR spin-lattice relaxation time $\left(T_{1}\right)$, indicating molecular dynamics of water, was determined in tall type, cv. Alaska and dwarf type, cv. Progress No. 9 in pea (Pisum sativum L.) epicotyls. The influence of the heat-denatured at $120^{\circ} \mathrm{C}$ for $15 \mathrm{~min}$ on $T_{1}$ in intact epicotyl tissues of seedlings from cv. Progress No. 9 is indicated (Fig. 1). After the heat treatment, $T_{1}$ values in intact tissues markedly decreased from $1.2 \mathrm{~s}$ to $0.7 \mathrm{~s}$. A similar tendency was observed in both elongation and no-elongation zones of epicotyls for pea cv. Alaska (data not shown), hypotoyls of mung bean (Vigna ratidata L.) (Iwaya-Inoue et al., 2000) and frog lens tissues (Neville et al., 1974). Change in $T_{1} \mathrm{~s}$ as function of temperature in the heat-denatured tissues exposed to $20-40^{\circ} \mathrm{C}$ thermal hysteresis is shown in Fig. 1. The $T_{1}$ values increased gradually with heating and decreased upon cooling. Therefore, a positive temperature dependency was clearly observed in $T_{1}$ for the heat-denatured dead tissues. In frozen-thawed sweet potato (Ipomoea batatas (L.) Lam.) tuber tissues, a positive temperature dependency of the Arrhenius plots was also clear in $T_{1}$ determined at temperatures ranging between 0 to $30^{\circ} \mathrm{C}$ (Iwaya-Inoue et al., $2004 \mathrm{a}$ ). These results were supported by the fact that temperature dependency in $T_{1}$ was observed in solutions in vitro (Iwaya-Inoue et al., 2004a). Therefore, the $T_{1}$ dependency in the dead plant tissues seems to solely reflect the mobility of water in the tissues.

\section{Changes in $T_{1}$ of tall and dwarf types for pea seedlings exposed to 30 or $40^{\circ} \mathrm{C}$ thermal hysteresis}

Initial values of $T_{1}$ in no-elongation zone of epicotyls for tall type pea, cv. Alaska, were significantly higher than those of elongation zone, respectively (Fig. 2, A, B). In addition, the initial values in $T_{1}$ of epicotyls for dwarf type, cv. Progress No. 9 (Fig. 2, C, D)., were higher than those of elongation zone of $\mathrm{cv}$. Alaska. It was indicated that the elevated $T_{1}$ value in dwarf type was not related to water content but to osmotic concentration (Iwaya-Inoue et al., 2003b). Thermal response on $T_{1}$ in both tall and dwarf types of pea plants exposed to $20-30^{\circ} \mathrm{C}$ heat-cool cycle is shown in Fig. $2 \mathrm{~A}$ and $\mathrm{C}$, respectively. $T_{1}$ in no-elongation zone of epicotyls of cv. Alaska was initially $1.1 \mathrm{~s}$ and it was almost constant or slightly decreased between 20 and $30^{\circ} \mathrm{C}$ (Fig. 2A). When the tissues were kept at $30^{\circ} \mathrm{C}$ $T_{1}$ markedly decreased to about $0.8 \mathrm{~s}$ and indicated constant value while $T_{1} \mathrm{~s}$ in elongation zone of $\mathrm{cv}$. Alaska did not change during heat-cool cycle. In Progress No. 9, $T_{1}$ slightly increased and it gradually decreased during $20-30^{\circ} \mathrm{C}$ thermal hysteresis (Fig. $2 \mathrm{C}$ ).

On the other hand, $T_{1}$ in no-elongation zone of cv. Alaska epicotyls was initially $1.1 \mathrm{~s}$ and it linearly increased between 20 and $40^{\circ} \mathrm{C}$, subsequently it gradually decreased at temperature equilibrium at $40^{\circ} \mathrm{C}$ followed by temperature decrease (Fig. 2B). Although the initial value of $T_{1}$ in elongation zone of $\mathrm{cv}$. Alaska was about $0.7 \mathrm{~s}$ and it was markedly lower than that of no-elongation zone, a similar tendency on temperature change was observed when they were heated to $40^{\circ} \mathrm{C}$. Additionally, $40^{\circ} \mathrm{C}$-thermal response on $T_{1}$ in epicotyls of cv. Progress No. 9 is shown in Fig. 2D. $T_{1} \mathrm{~S}$ of the dwarf cultivar kept the initial value and then gradually decreased during $20-40^{\circ} \mathrm{C}$ thermal hysteresis.

In pea seedlings exposed to the heat stress, there was no clear relationship between $T_{1}$ values and water contents (data not shown). $T_{1}$ values of mung bean seedling exposed 
to $40^{\circ} \mathrm{C}$ for $4 \mathrm{~h}$ decreased by 10 to $15 \%$, while water content decreased slightly (by less than $2 \%$ ) after the stress (Iwaya-Inoue et al., 1993). The decrease in $T_{1}$ was also observed in leaves of $6 \mathrm{wks}-$ old perennial ryegrass exposed to $50^{\circ} \mathrm{C}$, however, water contents decreased (Iwaya-Inoue et al., 2004b). These results suggested that relationship between $T_{1}$ and water content was affected by morphological characteristics and growth stage in the plant tissues.

\section{$\mathrm{GA}_{1}$-dose response on $T_{1} \mathrm{~S}$ in dwarf type of pea seedlings exposed to heat stress}

Epicotyls of cv. Progress No. 9 grown under light condition are extremely short compared to those of tall type, cv. Alaska, and exogenous $\mathrm{GA}_{1}$ on dwarf pea seedlings induces shoot growth. Red light suppresses the growth of the shoots of pea seedlings via a phytochrome-mediated response (Sponcel, 1986). It has been stated that A-2s were responsible for red light-induced growth inhibition in cv. Progress No. 9 (Noguchi and Hashimoto, 1990). Further, it was indicated that red light inhibited the shoot elongation of cv. Progress No. 9 much more than that of cv. Alaska and the difference in GA $3 \beta$ -hydroxylase between these cultivars was one replacement of alanine with threonine (Kato-Noguchi, 2002). Exogenous $\mathrm{GA}_{1}$ on cv. Progress No. 9 seedlings caused marked changes in $T_{1}$ level; $\mathrm{GA}_{1}$-dose induced decreased initial $T_{1}$ value in elongation zone while it increased $T_{1}$ in no-elongation zone (Iwaya-Inoue et al., 2003b). GA $A_{1}$-dose response on $T_{1}$ with temperature dependency is indicated by epicotyls of light-grown dwarf pea plants (Fig. $2 \mathrm{E}, \mathrm{F}$ ). Changes of $T_{1}$ in epicotyls of $\mathrm{GA}_{1}$-treated cv. Progress No. 9 indicated basically similar tendency observed in those in cv. Alaska during both $20-30^{\circ} \mathrm{C}$ and $20-40^{\circ} \mathrm{C}$ thermal hysteresis, respectively (Fig. 2 A, B). Kaku (1993) stated that leaves of azalea species with higher sensitivity to heat stress also exhibit higher sensitivity to drought stress, and vice versa. Although dwarf type indicated drought resistance (Iwaya-Inoue et al., 2003b), there was no marked difference in $T_{1}$ changes and heat sensitivity among tall type, dwarf type and $\mathrm{GA}_{1}$-dosed dwarf type.

\section{Reversible or irreversible change in $T_{1}$ s of pea seedlings exposed to subsequent heat-cool cycles}

In the heat-denatured dead pea epicotyls $T_{1}$ was dependent on temperature during the subsequent heat-cool cycles for $5 \mathrm{~h}$; it linearly decreased with decreasing temperature while it increased with increasing temperature (Fig. $3 \mathrm{~A}$ ). $T_{1} \mathrm{~S}$ for water and sugar solutions clearly reflected thermal response (Iwaya-Inoue et al., 2004a). Fig. 3B indicates $T_{1} \mathrm{~S}$ in fresh epicotyls of both elongation and no-elongation zones of cv. Alaska exposed to $20-40{ }^{\circ} \mathrm{C}$ replicated thermal hysteresis during $5 \mathrm{~h}$-treatment. $T_{1}$ linearly increased and it gradually decreased during $1 \mathrm{~h}$ while the subsequent thermal hysteresis, the second and the third exposure to the tissues, caused similar tendency observed in those of the heat-denatured dead tissues in the first heat-cool cyle (Fig. 1). On the contrary, $T_{1} \mathrm{~s}$ in fresh epicotyls of pea exposed to $30^{\circ} \mathrm{C}$ indicated noticeable difference in thermal response compared to those of $40^{\circ} \mathrm{C}$ treatment; $T_{1} \mathrm{~S}$ in fresh epicotyls of no-elongation zone of cv. Alaska kept marked shortening values at the subsequent thermal hysteresis during $5 \mathrm{~h}$ (Fig. $3 \mathrm{C}$ ). In addition, there was no temperature dependency in elongation zone of $\mathrm{cv}$. Alaska exposed to the same duration. Similar tendency was observed in both elongation and no-elongation zones of $\mathrm{GA}_{1}$-dosed cv. Progress No. 9. From these results, 
it was indicated that molecular dynamics of water in both heat-denatured and fresh tissues exposed to $40^{\circ} \mathrm{C}$ exhibited temperature-dependent hysteresis while pea epicotyls exposed to $30^{\circ} \mathrm{C}$ was temperature independent at subsequent heat exposure for 5 h-treatment.

It has been reported that treatment at $40^{\circ} \mathrm{C}$ to pea plants led to a serious injury of the photosynthetic parameters (Georgieva and Lichtenthaler, 1999). In this study, epicotyls of both cvs. Alaska and Progress No. 9 after the subsequent thermal hysteresis of $20-40^{\circ} \mathrm{C}$ cycles also indicated tissue necrosis. In contrast, the shortening of $T_{1}$ was observed at $40^{\circ} \mathrm{C}$ in perennial ryegrass leaves and these tissues indicated no severe injury (Iwaya-Inoue et al., 2004b). Additionally, a $3 \mathrm{~h}$ treatment at $40^{\circ} \mathrm{C}$ of pea (var. Douce Provence) plants induced production and accumulation of HSP22 in the matrix compartment of mitochondria (Lenne and Douce, 1994). Further, heat shock treatment $\left(40^{\circ} \mathrm{C}\right.$ for $4 \mathrm{~h}$ ) caused decreasing $T_{1}$ values in hypocotyls of mung bean and it induced a $70 \mathrm{kDa}$ protein and they were not severely injured (Iwaya-Inoue et al., 1993). Members of heat shock protein, HSP70 family has been shown in the same species (Kawata and Yoshida, 1988). Further, pea (cv. Feltham First) exposed to $37^{\circ} \mathrm{C}$ for $6 \mathrm{~h}$ accumulated $22 \mathrm{kDa}-$ HSPs and the response to heat shock was rapid with protein expression detected within $45 \mathrm{~min}$ (Wood et al., 1998). In yeast cells HSP70 family might stabilize denatured proteins and it might play a role as a surfactant in cells (Komatsu et al., 1990). These results suggested that shortening of $T_{1}$ and no temperature dependency in intact pea epicotyls exposed to $30^{\circ} \mathrm{C}$-thermal hysteresis might reflect cell adaptation to heat stress.

\section{Conclusion}

When pea plants were heated for $5 \mathrm{~h}$ at $20-40^{\circ} \mathrm{C}$ or $20-30^{\circ} \mathrm{C}$ thermal hysteresis, a reversible or irreversible change in $T_{1}$ was observed. The change in $T_{1}$ of epicotyls within $1 \mathrm{~h}$ was considered a fast adaptation or mortality in cells to heat stress. The $T_{1}$ corresponding temperature in the subsequent heat-cool cycles was notably different; epicotyls exposed to $30^{\circ} \mathrm{C}$ treatments, which were alive, did not show temperature dependency while those of the heat-denatured and fresh tissues exposed to $40^{\circ} \mathrm{C}$, which indicated tissue necrosis, were temperature dependency. Therefore, reversible changes in $T_{1}$ corresponding temperature reflected occurrence of tissue injury in pea epicotyls. From these results, $T_{1}$ on thermal response can be used as an indicator of tissue viability in an intact plant.

\section{Acknowledgment}

Seeds of pea cv. Progress No. 9 were kindly provided by Prof. Masayuki Katsumi (Emeritus), International Christian University.

\section{REFERENCES}

Farrar, T. C. and E. D. Becker 1971 Pulse and Fourier Transform NMR. Academic Press, New York (U. S. A.)

Franco, E., S. Alessandrelli, J. Masojidek, A. Margonelli and M. T. Giardi 1999 Modulation of D1 protein turnover under cadmium and heat stresses monitored by [S-35] methionine incorporation. Plant Sci., 144: 53-61

Galvis, M. L. E., S. Marttila, G. Hakansson, J. Forsberg and C. Knorpp 2001 Heat stress response in pea involves interaction of mitochondrial nucleoside diphosphate kinase with a novel 86-kilodalton 
protein. Plant Physiol., 126: 69-77

Georgieva K. and H. K. Lichtenthaler 1999 Photosynthetic activity and acclimation ability of pea plants to low and high temperature treatment as studied by means of chlorophyll fluorescence. J. Plant Physiol., 155: 416-423

Ishida, N., M. Koizumi and H. Kano 2000 The NMR microscope: unique and promising tool for plant science. Ann. Bot., 86: 259-279

Iwaya-Inoue, M., K. Sakaguchi and S. Kaku 1989 Statistical studies using AIC methods to decide the question of "Break" or "Straight" in Arrhenius plots of water proton NMR relaxation times in chilling-sensitive Vigna and insensitive Pisum seedling. Plant Cell Physiol., 30: 309-361

Iwaya-Inoue, M., K. Yoshimura, H. Yamasaki and S. Kaku 1993 Characteristic changes in relaxation times of water proton in Vigna radiata seedlings exposed to temperature stress. Plant Cell Physiol., 34: 705-711

Iwaya-Inoue, M., K. Yoshimura, M. Otsubo and H. Yamasaki 2000 Effects of oxygen stress on 'H-NMR relaxation time $\left(T_{1}\right)$ of Vigna radiata seedling. J. Fac. Agr. Kyushu Univ., 44: 249-256

Iwaya-Inoue, M. and H. Nonami 2003a Effects of trehalose on flower senescence from the view point of physical states of water. Environ. Cont. Biol., 41: 3-15

Iwaya-Inoue, M., K. Motooka, Y. Ishibashi and M. Fukuyama 2003b Characteristic water status in dwarf pea in relation to drought resistance. J. Fac. Agr. Kyushu Univ., 48: 29-38

Iwaya-Inoue, M., R. Matsui, N. Sultana, K. Saitou, K. Sakaguchi and M. Fukuyama 2004a ${ }^{1} H-N M R$ method enables early identification of degeneration in the quality of sweet potato tubers. J. Agr. Crop Sci, 190: 1-8

Iwaya-Inoue, M., R. Matsui and M. Fukuyama 2004b Cold- or heat-tolerance of leaves and roots in perennial ryegrass determined by 'H-NMR. Plant Pro.Sci., 7: In press

$\mathrm{Kaku}$, S. and M. Iwaya-Inoue 1988 Monitoring primary response to chilling stress in etiolated Vigna radiata and $V$. mungo seedlings using thermal hysteresis of water proton NMR relaxation times. Plant Cell Physiol., 29: 1063-1068

Kaku, S. 1993 Monitoring stress sensitivity by water proton NMR relaxation times in leaves of azaleas that originated in different ecological habitats. Plant Cell Physiol., 34: 534-541

Kato-Noguchi, H. 2002 Effects of red light on gibberellin $3 \beta$-hydroxylase gene expression in dark-grown seedlings of dwarf and tall cultivars of Pisum sativum. J. Plant Physiol., 159: 607-612

Kawata, T. and S. Yoshida 1988 Alterations in protein synthesis in vivo in chilling sensitive mung bean hypocotyls caused by chilling stress. Plant Cell Physiol., 29: 1423-1427

Komatsu, Y., S. C. Kaul, H. Iwahashi and K. Obuchi 1990 Do heat shock protein provide protection against freezing? FEMS Microbiol. Lett., 72: 159-162

Kurganova, L. N., A. P. Veselov, Y. V. Sinitsina and E. A. Elikova 1999 Lipid peroxidation products as possible mediators of heat stress response in plants. Russian J. Plant Physiol., 46: 181-185

Lenne, C. and R. Douce 1994 A low molecular mass heat-shock protein 1s localized to higher plant mitochondria. Plant Physiol., 105: 1255-1261

Neville, M. C., C. A. Patterson, J. L. Rae and D. E. Wossner 1974 Nuclear magnetic resonance studies and water "ordering" in the crystalline lens. Science, 184: 1072-1074

Noguchi, H. and T. Hashimoto 1990 Phytochrome-mediated synthesis of novel growth inhibitors, A-2 $\alpha$ and $\beta$, and dwarfism in peas. Planta, 181: 256-262

Salvucci, M. E., K. W. Osteryoung, S. J. Crafts-Brandner and E. Vierling 2001 Exceptional sensitivity of rubisco activase to thermal denaturation in vitro and in vivo. Plant Physiol., 127: 1053-1064

Sponcel, V. M. 1986 Gibberellins in dark-and light-grown shoots of dwarf and tall cultivars of Pisum sativum. Planta, 168: 119-129

Suzuki, T. C., D. C. Krawitz and E. Vierling 1998 The chloroplast small heat-shock protein oligomer is not phosphorylated and does not dissociate during heat stress in vivo. Plant Physiol., 116: 1151-1161

Wood, C. K., J. R. Pratt and A. L. Moore 1998 Identification and characterization of cultivar-specific 22-kDa heat shock proteins from mitochondria of Pisum sativum. Physiol. Plant., 103: 369-376 